\title{
Interventions for Ensuring the Sustainability of the Small Scale Mining Sector in Namibia
}

\author{
Harmony K. Musiyarira*, Ditend Tesh, Mallikarjun Pillalamarry and Nikowa Namate \\ Department of Mineral and Process Engineering, Namibia University of Science and Technology, Windhoek, Namibia
}

\begin{abstract}
Many reports have been written about the issues surrounding small scale miners' challenges in Namibia; yet little has been done to address these challenges. There has been a fragmented approach to address these challenges. Various government arms and donor organizations have utilized piece meal methods in the past in trying to make improvements on the productivities across the sector, but with no meaningful success. This has led to the design and implementation of inappropriate technologies and support services for the sector. The structures of many of the semi-precious stones mining businesses are informal, with very little royalties received by the government. Miners often work informally or illegally and they fear government interference and they distrust outsiders, resulting in them withholding production information. The presence of small scale miners is quite often associated with major challenges, including poor safety and environmental management standards, the spread of communicable diseases and poor working conditions. The majority of the miners employ uncontrolled extraction techniques which damage the crystals and mineral specimens, resulting in intermediate and final products of low quality along with high wastage at the extraction stage. The vision of the Namibian government is to expand the range and value of semi-precious stones and jewelry products processed within Namibia, while curbing illicit flows of raw stones. This will simultaneously secure maximum benefit for the country. This study investigated the interventions aimed at making the small scale mining sector in Namibia sustainable. A baseline study was conducted to analyze the current situation and characterize the industry, including a SWOT analysis. Information was collected through questionnaires, interviews, consultative meetings, field visits and workshops in order to profile the sector. The baseline study results were used in developing interventions for improving artisanal and small scale mining operations. The main challenges for the Namibian semi-precious sector were identified as: factual information about raw material resources and its beneficiation are insufficient or not available, lack of skills, lack of education and access to finances, rudimentary exploration and mining practices, trading and logistics that are not functioning effectively and inadequate sector governance. One key finding of this study was that Namibia is not benefiting through value addition due partly to illicit flows of the uncut stones and to the fact that lapidary is not much pronounced to a greater extent. The following strategic interventions were identified as key in ensuring the sustainability of the small mining sector in Namibia: conducting geological assessment to identify new deposits and quantify the existing ones, improving exploration and mining practices, investing in education and training, creating an enabling environment and improving the sector governance and strengthening the sector organization and supporting the infrastructure.
\end{abstract}

Keywords: appropriate technologies, interventions, small scale miners, semi-precious stones, value addition

\section{Introduction / Background}

Small-scale mining in the world over and Africa in particular, is plagued with many problems including inadequate legal and regulatory frameworks, low productivity, and the application of rudimentary and inappropriate technology. The industry is also faced with problems such as isolation from the mainstream of economic development, adverse environmental effects, health and occupational hazards (Haye 2008). The vision of the Namibian government is to promote the mining of semiprecious stones while curbing illicit flows of raw stones and simultaneously securing the maximum benefit for the country through value addition.

* Corresponding Author: H.K. Musiyarira, hmusiyarira@nust.na, phone: +264 61-2072076

Copyright @ 2017 Canamaple Academia Services, http://press.camdemia.ca
A variety of gem quality semi-precious stones are currently mined in Namibia, a proportion of which are recovered intermittently by artisanal small-scale miners and prospectors. Moreover, trading of Namibian's semi-precious stones on the international market is not uncommon and these stones fetch higher prices in the market in comparison to what the small scale miners in Namibia get when they sell them to tourists and dealers. While many reports have been written about the issues surrounding small scale mining and the semi-precious value chain challenges, little has been done in the way of implementation of these findings. There have been fragmented approaches to address these challenges, without any consolidated efforts to address and mitigate the sustainability issues of the semi-precious stones sector. The pressure to deliver equipment to stone centers swiftly without a broader semi-precious sector growth 
strategy is believed to constrain the scope for innovation and correction in the sector (Musiyarira et al 2016). The lack of structured and formalized coordination between different government ministries costs the government money which could have been put to good use by combining efforts across various ministries. This lack of knowledge has led to the design and implementation of inappropriate technologies and support services for the sector. This study investigated the interventions aimed at making the small scale mining sector in Namibia sustainable.

\section{Semi-Precious Stones}

Since the colonial period, Namibia has been known for its wide variety of quality semi-precious stones. Most of the Namibian semi-precious stones are mined by artisanal small scale miners and prospectors. These stones are mostly mined in three regions of Namibia, namely Karas, Erongo and Kunene. Semi-precious stones mined in Namibia include quartz (rose, clear, strawberry and smoky), tourmaline, sodalite, topaz, varieties of beryl (aquamarine, heliodore and morganite), garnet and amethyst among others. Tourmaline remains to this day an important semiprecious commodity together with amethyst, rose quartz and smoky quartz. The small-scale production of dioptase, chrysocolla and pyrophyllite is also noteworthy (MITSMED Report 2016).

Most of the Namibian semi-precious stones are recovered from late Pan African pegmatites, while amethyst is currently produced from a deposit hosted by Damaran marbles. Production in the early days was not always well controlled or reported, so the cumulative production figures may not be accurate. Moreover, semi-precious stones mining in Namibia are considered as a small scale mining activity and its history is not well documented. The semiprecious stones industry is made up of Small and Medium Scale Enterprises (SMEs) and they are the building blocks of the industry, as most people depend on them for survival. These SMEs are merely individuals, family operated businesses and close cooperation employing not more than ten people per company.

\subsection{Small scale miners}

Artisanal and small-scale mining (ASM) takes place throughout the world, but it is particularly widespread in Africa, Asia, Oceania, and Central and South America. In Africa alone, nearly 9 million people depend on artisanal and small-scale mining, who, with their dependents, account for nearly $8 \%$ of the population of the continent (Hayes 2008). There is no universal definition of ASM (Andrew 2003, Hinton 2006), and some commentators argue that the only characteristic that can be universally applied to ASM is the "impossibility of defining it according to any universal parameters" (Ávila 2003). Different countries define ASM in their legislation according to different criteria, such as volume of production, volume of output, the amount of capital invested, the size of the workforce, the size of a claim, the depth of the mine, and/or the level of sophistication of the mining equipment used (Andrew 2003,
Ávila 2003). The variation between countries in terms of both the choice of variables used and the value they are given means that it is difficult to achieve consensus on what constitutes ASM (Andrew 2003, Hinton 2006).

In Namibia the majority of semi-precious stone mining businesses are informal, with very little paid to the state in royalties. Miners often work informally or illegally and there is widespread fear of government interference and distrust of outsiders, resulting in them withholding information. This makes it difficult to control clandestine activities, illegal migration or trading outside legal channels (Dreschler 2001). This informal structure has resulted in the government not having reliable data and information about the sector. The lack of data on small scale mining is a key challenge for government authorities and other key stakeholders to develop effective policies and programmes (Banchirigah 2008, Cook and Healy 2012). Consequently, these mining activities result in the violation of national labor, environmental, and other regulations. However, small scale mining activities taking place in many regions of the country play a significant role, both as a direct source of employment and also generating revenues into the rural economy (Mupewa 2014). The presence of small scale miners is quite often associated with major challenges, including poor safety and environmental management standards, spread of communicable diseases and poor working conditions. The majority of the miners employ uncontrolled extraction techniques which damage crystals and mineral specimens, resulting in intermediate and final products of low quality and high wastage at the extraction stage.

\section{Major Constraints}

There is poor coordination of what is and is not known about the sector and a large amount of practice-informed knowledge is not documented or publicly shared. Buxton (2013) poses a fundamental question; "Without information about communities, baseline geological data, and knowledge of indigenous practices, how can appropriate technologies, policies and assistance schemes be devised and implemented?" A major challenge for the semi-precious stones sector is that the value chain does not function in a way that would maximize the Namibian value addition. Apart from this, the Namibian semi-precious stones industry has been facing numerous other challenges and its contribution to the development of the national economy is unaccounted for. Some of these challenges are analyzed in detail in sections 3.1 to 3.6 and these are illustrated in Table 1. It can be seen that the major challenges are access to finances, equipment, stone processing, access to market and social issues, such as child labor, etc.

\subsection{Exploration}

A major challenge in many countries is the lack of geological information indicating mineralized areas for small scale miners' concessions. Literature studies reveal that there is a general lack of reliable data about the scale and scope of ASM production and target ASM populations 
is a key challenge for government authorities and other key stakeholders looking to develop effective policies and programmes (Banchirigah 2008, Cook and Healy 2012). According to Hilson and Maponga (2004), there is an "acute shortage of baseline census and geological information" on ASM. A few governments from the developing world possess detailed geological maps in forms which are easily usable by small-scale miners (Aryee et al 2003, Hilson \& Maponga 2004, Collins and Lawson 2014). Semi-precious stone mineral deposits in Namibia are geologically mapped but not to a great extent; and little updated and accurate information is available. Without information about baseline geological data and knowledge of indigenous practices, it is very difficult to devise and implement appropriate technologies, policies and assistance schemes. On the other hand, the industry does not have the capacity to utilize the available information. As a result, most miners carry out ad hoc operations, largely a guesswork or trial and error method to estimate the resources. These methods often result in investment losses for small-scale miners, low mineral recovery and less or no government revenue.

Table 1. Small scale mining challenges.

\begin{tabular}{|ll|ll|}
\hline Geology \& Technology & \multicolumn{2}{|c|}{ Business / Marketing } \\
\hline$\circ$ & Lack of equipment & $\circ$ & Lack of capital \\
$\circ$ & Wrong mining methods & $\circ$ & Lack of business appreciation \\
$\circ$ & $\begin{array}{l}\text { Lack of geological information } \\
\text { indicating mineralized areas }\end{array}$ & $\circ$ & $\begin{array}{l}\text { Access to market via } \\
\text { intermediaries }\end{array}$ \\
$\circ$ & High losses of value and time & $\circ$ & Market barriers Price valuation \\
\hline Social Aspects & \multicolumn{2}{|c|}{ Safety Health and Environment } \\
\hline$\circ$ & Child labor emphasis on & $\circ$ & Water, air \& soil pollution \\
& education & $\circ$ & Land degradation \\
$\circ$ & Violence \& crime & $\circ$ & Accidents \\
$\circ$ & Conflicts with farmers & $\circ$ & Exposure to hazards \\
$\circ$ & Gambler mentality & & \\
$\circ$ & Unskilled labor force & & \\
$\circ$ & Lack of social security & & \\
\hline
\end{tabular}

\subsection{Risk and safety management}

Mining techniques used by small scale miners are rudimentary and unsafe. As a consequence, the miners cannot go far deep into the ground to extract the semiprecious stones. This results in poor recovery and wastage of valuable resources. The pits dug by the miners are not reclaimed, thereby posing a danger for animals and the miners themselves (Musiyarira et al 2016). Moreover, these pits are potential sources of acid mine drainage, leading to the contamination of ground and surface water. In many countries across the world, including Namibia, measures for the prevention of mining accidents and other fatalities in small scale semi-precious stones mining are not implemented. Health problems such as dust causing silicosis and noise causing tinnitus are evident in small-scale mining areas in Namibia (MITSMED 2016). In addition to these health problems, there are cases of physical injury within the mines due to rock falls and mine collapses. Digging in the fierce Namibian heat with basic hand tools is hard and often unsafe, particularly in locations such as the Erongo mountains, where miners work at greater heights without protective equipment. The locations are usually very isolated with no sanitation and with imported water supplies.

\subsection{Access to finance}

Access to finance or a lack thereof has a ripple effect on the small-scale mining of gemstones. On many occasions the miners do not have starting capital in order to acquire the tools they require. Moreover, financial institutions and investors are reluctant to finance the small-scale mining business as it is considered to be too risky.

\subsection{Skills}

Education and training is the cornerstone for promoting the formalization of the sector, as well as creating awareness of health and safety hazards and minimizing the environmental impacts of ASM (Aryee et al 2003). In the Namibian context there is a need to identify training needs for miners, processors, jewelers, traders and the other critical actors in the semi-precious stone value chain. If this capacity is built, Namibia can be an innovation, research and education hub of gemmological applied sciences, contributing to the local, regional and continental self-sustainability and beneficiation of the gemstone industry (MITSMED 2016).

\subsection{Marketing and trade}

The role of mineral traders and "middle men" is crucial for the functioning of the chain in many instances. Traders typically provide pre-financing which enables the miners to purchase tools, pay entry fees to mines, and to support their families during periods of transition or when mineral returns are low. Whilst this access to credit is an essential function, it also creates debt relationships which, at their most benign, can result in preferential pricing for the traders and, at worst, can result in a debt burden which acts as a trap which is prohibiting exit from the sector. The debt can even be passed on to the next generation (Hayes 2008).

With the extensive development of e-commerce tools, most of the semi-precious stone dealers around the world trade their stones online. However, the Namibian semiprecious stones sector is not fully utilizing the online trading of their semi-precious stones. Exported raw Namibian stones are being sold online by foreign traders to other countries. The Namibian semi-precious stone industry is also threatened by synthetic stones being sold on the market to unsuspecting buyers. The synthetic stones in most cases look exceptionally better in terms of color and clarity. To a common person, it is a challenge to distinguish between synthetic and natural stones.

\subsection{Legal framework and policy}

The absence of adequate legal frameworks and secure rights for miners and communities is another challenge for the sector. Local governance structures and institutions are typically underdeveloped. The lack of an attractive policy framework has also imposed significant constrains on the gems and jewelry sector. Historically, the sector has received very little attention from the government. Although the government has recently introduced some positive policy reforms due to the efforts of the Growth at Home strategy, additional improvements are needed in order to make the sector more competitive. Obtaining a mining claim 
license is a tedious and time-consuming process involving different government agencies and technical requirements (pegging of claim, obtaining of environmental contract) which make it difficult for SSMs to acquire the license. There is also a high degree of informality and fragmentation in the value chain (at mining, trading and even processing level), resulting in a lack of a reliable database on the industry performance and overall relevance for the Namibian economy. Small-scale miners fear government interference and they distrust outsiders; as a result, they tend to withhold information. There is also very little coordination between different stakeholders (government departments, non-governmental organizations and miners' associations) when it comes to the semi-precious stones sector.

\section{Methodology}

A baseline study was conducted to analyze the current situation and characterize the industry, including a SWOT analysis. Information was collected through questionnaires, interviews, consultative meetings, field visits and workshops in order to profile the sector. The baseline study results were used in coming up with interventions for improving artisanal and small scale mining operations. The research team collected basic relevant data and information on policy, institutional, resource use, legal and regulatory frameworks for the sustainability of the small scale mining in Namibia. Since the semi-precious stones industry is spread over different regions in Namibia, one day consultative meetings with the small scale miners in each of the mining regions were conducted. These consultative meetings fed into the planning workshop which was conducted with the stakeholders to discuss the SWOT analysis outcomes. The outcome of the participatory two days' workshop was the "Objective Tree", which identifies the main objectives to be implemented in the sector. The logical framework approaches, coupled with the SWOT analysis were essential techniques used in the formulation of a set of strategic objectives.

\section{Results}

The following strategic interventions were identified as key in ensuring the sustainability of the small scale mining sector in Namibia; ensuring primary production and supply, enhancing support, services delivery, and improving the sector governance.

\subsection{Primary production, sourcing and input}

The main strategic intervention is to ensure a sufficient supply of raw gemstones for local processing and manufacturing activities by improving primary production and making trade in rough gemstones more efficient and transparent. This can be achieved through increasing knowledge of gemstone resources in Namibia by completing gemstone exploration and resource estimation for at least $10 \%$ of the area in Namibia by the year 2020. Improving access to appropriate technology to cover at least $25 \%$ of entrepreneurs and enterprises and increasing the share of locally processed rough gemstones to $25 \%$ of total value of reported annual production of natural colored gemstones in Namibia is also key in realizing this goal. Table 2 shows the key strategic actions necessary to achieve this goal.

Table 2. Proposed interventions for primary production, sourcing and input supply.

\begin{tabular}{|l|l|}
\hline Major interventions & \multicolumn{1}{|c|}{ Key activities } \\
\hline \multirow{5}{*}{$\begin{array}{l}\text { Invest in education, } \\
\text { training, skills } \\
\text { transfer and } \\
\text { empowerment }\end{array}$} & $\begin{array}{l}\text { Develop and provide basic education and } \\
\text { training skills in gemology and jewelry design } \\
\text { and manufacturing }\end{array}$ \\
\cline { 2 - 3 } & $\begin{array}{l}\text { Establishment of a semi-precious stone } \\
\text { Capacity Enhancement Centre to offer } \\
\text { extension services (e.g. mining equipment, } \\
\text { exploration, testing and laboratory equipment, } \\
\text { valuation and short business appreciation } \\
\text { courses) }\end{array}$ \\
\cline { 2 - 3 } Supporting Service & $\begin{array}{l}\text { Upgrade existing training centers to provide } \\
\text { short-term courses in collaboration with } \\
\text { international institutions to provide training } \\
\text { opportunities }\end{array}$ \\
\hline & $\begin{array}{l}\text { Establish semi-precious identification and } \\
\text { certification laboratories to ensure better } \\
\text { understanding of gemstones and their } \\
\text { properties }\end{array}$ \\
\cline { 2 - 2 } & $\begin{array}{l}\text { Establish gem exchange centers to facilitate } \\
\text { linkages between buyers and sellers }\end{array}$ \\
\cline { 2 - 2 } & $\begin{array}{l}\text { Provide technical assistance in } \\
\text { Prospecting and exploration and extracting } \\
\text { techniques which preserve the gemstones' } \\
\text { quality }\end{array}$ \\
\hline
\end{tabular}

\subsection{Support service delivery}

The main strategic intervention is to support the semiprecious stone sector by investing in education and empowerment and other supporting services (financial services and operational services). This can be achieved through training about $50 \%$ of miners in sustainable mining and business practices by the year 2020 and establishing gem exchange centers and semi-precious identification and certification centers to evaluate the semi-precious stones and facilitate linkages between buyers and sellers by the year 2020. Table 3 shows the key strategic actions necessary to achieve this goal.

Table 3. Proposed interventions for support services delivery.

\begin{tabular}{|l|l|}
\hline \multicolumn{1}{|c|}{ Major interventions } & \multicolumn{1}{|c|}{ Key activities } \\
\hline $\begin{array}{l}\text { Mapping of gemstone } \\
\text { deposits and dissemination } \\
\text { of information }\end{array}$ & $\begin{array}{l}\text { Conduct geological survey to identify } \\
\text { new deposits }\end{array}$ \\
\cline { 2 - 2 } & $\begin{array}{l}\text { Mapping existing gemstone varieties } \\
\text { and their resources across the country }\end{array}$ \\
\hline $\begin{array}{l}\text { Support for the adoption of } \\
\text { good exploration and } \\
\text { mining practices }\end{array}$ & $\begin{array}{l}\text { Development of guidelines for choosing } \\
\text { appropriate techniques for mining the } \\
\text { gemstone deposits }\end{array}$ \\
\cline { 2 - 2 } & $\begin{array}{l}\text { Train/educate the miners in latest } \\
\text { mining and exploration methods }\end{array}$ \\
\hline $\begin{array}{l}\text { Design and implementation } \\
\text { of independent and } \\
\text { transparent valuation and } \\
\text { trading mechanisms for } \\
\text { rough stones }\end{array}$ & $\begin{array}{l}\text { Conduct feasibility study to establish } \\
\text { regional valuation and trading centers }\end{array}$ \\
\cline { 2 - 2 } & $\begin{array}{l}\text { Create regional gemstone independent } \\
\text { valuation hubs }\end{array}$ \\
\cline { 2 - 2 } & $\begin{array}{l}\text { Establish regional gemstone trading } \\
\text { hubs }\end{array}$ \\
\hline
\end{tabular}




\subsection{Regulatory and institutional framework and conditions}

The main strategic intervention is to create an enabling environment for the growth of local processing and manufacturing activities and improve value chain governance through better stakeholder coordination and cooperation. This can be achieved through amending and introducing new policies for the sector and improving the reporting and control of production, import and export statistics of the sector and having at least one regional office per region for processing license applications by the year 2020. The government has a pivotal role to play in defining the policy and legal framework, incentives, and processes which determine if ASM is carried out informally or if it can become more integrated into the mainstream economy. Table 4 shows the key strategic actions necessary to achieve this goal.

Table 4. Proposed interventions, regulatory and institutional framework and conditions.

\begin{tabular}{|c|c|}
\hline Major interventions & Key activities \\
\hline \multirow{4}{*}{$\begin{array}{l}\text { Improve the reporting } \\
\text { structure and } \\
\text { mechanism for the } \\
\text { sector }\end{array}$} & $\begin{array}{l}\text { Simplify documentation and clearance } \\
\text { procedures and publish export procedures } \\
\text { and documentation to encourage } \\
\text { compliance }\end{array}$ \\
\hline & $\begin{array}{l}\text { Decentralize license processing } \\
\text { Develop simplified and streamlined } \\
\text { procedures for issuing mining licenses } \\
\text { Pegging of claims }\end{array}$ \\
\hline & Environmental contract \\
\hline & Decentralize the reporting structure \\
\hline \multirow{3}{*}{$\begin{array}{l}\text { Creating an enabling } \\
\text { environment and } \\
\text { improving the sector } \\
\text { governance }\end{array}$} & $\begin{array}{l}\text { Review import/export duties to remove } \\
\text { anomalies hindering the industry's growth }\end{array}$ \\
\hline & $\begin{array}{l}\text { Review import/export duties to remove } \\
\text { anomalies hindering the industry's growth }\end{array}$ \\
\hline & $\begin{array}{l}\text { Provision of support for the formation of } \\
\text { relevant associations and cooperatives }\end{array}$ \\
\hline
\end{tabular}

\section{Conclusions}

Many reports have been written about the issues surrounding small scale miners' challenges in Namibia; yet little has been done to address these challenges. There has been a fragmented approach to address these challenges. Various government arms and donor organizations have utilized piece meal methods in the past in trying to make improvements on the productivities across the sector, but with no meaningful success. This has led to the design and implementation of inappropriate technologies and support services for the sector. The vision of the Namibian government is to expand the range and value of semiprecious stones and jewelry products, processed within Namibia, while curbing illicit flows of raw stones. This will simultaneously secure maximum benefit for the country. This study investigated the interventions aimed at making the small scale mining sector in Namibia sustainable. The main challenges for the Namibian semi-precious sector were identified as; factual information about raw material resources and its beneficiation are insufficient or not available, lack of skills, lack of education and access to finances, rudimentary exploration and mining practices, trading and logistics are not functioning effectively and inadequate sector governance. One key finding of this study was that Namibia is not benefiting through value addition due partly to illicit flows of the uncut stones and to the fact that lapidary is not much pronounced to a greater extent. The following strategic interventions were identified as key in ensuring the sustainability of the small mining sector in Namibia; conducting geological assessment to identify new deposits and quantify the existing ones, improving exploration and mining practices, investing in education and training, creating an enabling environment and improving the sector governance and strengthening the sector organization and supporting the infrastructure. It was found that the main catalyst for the growth of the semi-precious stone sector is to consider all the unit chains/processes within the value chain as being part of the systems which need to be improved at each and every stage for the common good of the whole sector.

\section{Acknowledgement}

The authors would like to express their sincere gratitude to the Vice Chancellor and senior management of the Namibia University of Science and Technology for their unwavering support and interest in minerals education. We are grateful to the Namibian Ministry of Industrialization, Trade and SME Development for sponsoring this study.

\section{References}

Andrew, J.S., 2003. Potential application of mediation to land use conflicts in small-scale mining. Journal of Cleaner Production, 11(2): 117 - 130.

Aryee, B.N., B.K. Ntibery and E. Atorkui, 2003. Trends in the small-scale mining of precious minerals in Ghana: a perspective on its environmental impact. Journal of Cleaner production, 11(2): 131 - 140.

Banchirigah, SM 2008, 'Challenges with eradicating illegal mining in Ghana: A perspective from the grassroots', Resources Policy, vol. 33, no. 1, pp. 29-38.

Buxton, A., 2013. Responding to the challenge of artisanal and small-scale mining. Feb 2013 - IIED.

Ávila, E.C., 2003. Small-scale mining: a new entrepreneurial approach. Cepal Review, 80p.

Collins, N. and L. Lawson, 2014. Investigating approaches to working with artisanal and small-scale miners: A compendium of strategies and reports from the field. International Mining for Development Centre.

Cook, F.A., 2002. Geophysical methods used in exploration for gemstones, CSEG recorder.

Cook, R. and T. Healy, 2012. Madagascar case study: artisanal mining rushes in protected areas and a response toolkit: Artisanal and small-scale mining in and around protected areas and critical ecosystems project (ASM-PACE). Estelle Levin Ltd \& WWF.

Dreschler, B., 2001. Small-scale mining and sustainable development within the SADC region. Mining, Minerals and Sustainable Development, 84. 
http://pubs.iied.org/pdfs/G00735.pdf. Accessed on March 13, 2015.

Hayes, K., 2008. Artisanal and small-scale mining and livelihood in Africa. Common Fund for Commodities, Amsterdam.

Hilson, G. and O. Maponga, 2004. How has a shortage of census and geological information impeded the regularization of artisanal and small- scale mining? Natural Resources Forum, 28(1): 22 - 33.

Hinton, J., 2006. Communities and small scale mining: An integrated review for development planning. Report to the World Bank.

MITSMED (Ministry of Industrialization, Trade and SME Development), 2016. Growth strategy for the Namibian jewellery industry and coloured gemstone and associated value chains. http://www.mti.gov.na/downloads/Jewellery\%20and\%2 0Gemstones_Strategies_Web.pdf. Accessed on March $13,2017$.

Mupewa, I., 2014. How small-scale mining can contribute to economic development and environmental sustainability in Namibia. Light \& Gems: Ministry of Mines and Energy Newsletter.

Musiyarira, H., D. Tesh, N. Namate and M. Pillalamarry, 2016. Establishing the essential building blocks for the semi-precious industry. Proceedings of the Mining Communities 2016 Conference, Vancouver, Canada. 